\title{
Erratum: Chromium and Manganese Levels in Biological Samples of Pakistani Myocardial Infarction Patients at Different Stages as Related to Controls
}

\author{
Hassan Imran Afridi • Tasneem Gul Kazi • Naveed Kazi • Sirajuddin • \\ Ghulam Abbas Kandhro • Jameel Ahmed Baig • Abdul Qadir Shah • \\ Mohammad Khan Jamali • Mohammad Balal Arain • Sham Kumar Wadhwa • \\ Sumaira Khan • Nida Fatima Kolachi • Faheem Shah
}

Published online: 23 December 2010

(C) Springer Science+Business Media, LLC 2010

\section{Erratum to: Biol Trace Elem Res DOI 10.1007/s12011-010-8773-3}

The original version of this article unfortunately contained mistakes.

In Table 2, the units of white blood cell count and platelet count should be $\mathrm{K} / \mathrm{mm}^{3}$, while $\mathrm{M} / \mathrm{mm}^{3}$ for red blood cell count.

The online version of the original article can be found at http://dx.doi.org/10.1007/s12011-010-8773-3.

H. I. Afridi • T. G. Kazi - Sirajuddin • G. A. Kandhro • J. A. Baig • A. Q. Shah • M. K. Jamali • M. B. Arain · S. Kumar Wadhwa S. Khan • N. F. Kolachi ·. Shah

National Center of Excellence in Analytical Chemistry, University of Sindh, Jamshoro 76080, Pakistan

T. G. Kazi

e-mail: tgkazi@yahoo.com

J. A. Baig

e-mail: jab_mughal@yahoo.com

M. K. Jamali

e-mail: mkhanjamali@yahoo.com

M. B. Arain

e-mail: bilal_ku2004@yahoo.com

F. Shah

e-mail: shah_ceac@yahoo.com

H. I. Afridi $(\bowtie)$

Mechanical and Manufacturing Engineering, Dublin City University, Dublin, Ireland e-mail: hassanimranafridi@yahoo.com

N. Kazi

Liaquat University of Medical and Health Sciences, Jamshoro, Pakistan e-mail: tgkazi@yahoo.com 